Dariusz Piotrowski

ORCID: 0000-0002-8811-9318

Uniwersytet Jagielloński

https://doi.org/10.19195/1733-5779.33.14

\title{
Czy druga izba parlamentu jest potrzebna? Rozważania na temat bikameralizmu w ujęciu historyczno-komparatystycznym
}

\author{
JEL Classification: K16, K19, K38
} Sejm

Słowa kluczowe: parlament dwuizbowy, izba wyższa, bikameralizm asymetryczny, Senat,

Keywords: bicameral parliament, Upper Chamber, asymmetrical bicameralism, the Senate, the Sejm

Abstrakt: Współczesne systemy parlamentarne, oparte na osiemnastowiecznych ideach suwerenności ludu, w znaczącej części składają się z unikameralnych organów legislacyjnych. Trend ten, zaznaczający się w ostatnim półwieczu, wypiera powoli tradycyjne dwuizbowe ciała, na co wskazują statystyki Unii Międzyparlamentarnej.

Wywodzące się z instytucji rad królewskich organy mają bardzo bogatą historię. Ich genezy można doszukiwać się $\mathrm{w}$ islandzkim Althingu oraz średniowiecznych zjazdach germańskich. Tradycyjny parlament, ukształtowany w Anglii, stał się instytucją modelową, torując drogę ciałom złożonym z więcej niż dwóch izb. Współcześnie jednak badacze próbują odnaleźć fenomen w czterech modelach dwuizbowości: nordyckiej, izby samorządowej, federalnej oraz refleksji i rozwagi. Autor artykułu próbuje znaleźć rozwiązanie tego problemu w Polsce, podejmując się historycznego i komparatystycznego porównania, kładąc nacisk na współczesne działania ustawodawcze.

\section{Is the senate necessary nowadays? Considerations on bicameralism in historical and comparative terms}

Abstract: Based on the 17th century ideas of sovereignty of the people, modern parliamentary systems to a substantial degree consist of unicameral bodies. This trend, marked in the last

* Opiekun naukowy (Scientific Tutor) — dr hab. Marcin Spyra 
half-century, is slowly displacing traditional bicameral bodies, according to Inter-Parliamentary Union statistics.

Parliaments derived from the institution of royal councils have a rich history. It is reasonable to look for their origin in Icelandic Althing and medieval German conventions. The English traditional parliament became the model institution, showed the way to bodies composed of more than two chambers. In our age researchers attempt to discover the phenomenon in four types of bicameralism: the Nordic, federal, self-governmental chambers, and house of "prudence".

The author of the article tries to find an adequate solution to this problem in Polish conditions, taking on historic and comparative comparison, focusing on modern legislative actions.

Współczesne państwa, opierając swe działania na osiemnastowiecznej idei suwerenności ludu, dążą do zagwarantowania jak najszerszego uczestnictwa obywateli w sprawowaniu władzy politycznej. Bez wątpienia najistotniejszym narzędziem, mającym na celu bezpośrednie wyrażanie woli narodu w sprawach politycznych, są wybory, z którymi ściśle związana jest instytucja parlamentu pełniącego funkcję najważniejszego organu przedstawicielskiego, dzierżącego najwyższą władzę ustawodawczą. Burzliwe dzieje tego gremium mającego swe korzenie w średniowiecznej Europie dowodzą jedynie jego znaczącej funkcji zarówno w przeszłości, jak i dziś. Mimo istnienia różnych teorii demokracji, koncentrujących się na jednym $\mathrm{z}$ aspektów jej funkcjonowania współcześni badacze często skupiali się na pragmatycznym problemie uformowania organu przedstawicielskiego, jego funkcji oraz strukturze. Poszukiwania idealnego parlamentu nasiliły się po upadku systemu komunistycznego i próbie uformowania nowoczesnych demokracji przez byłe państwa bloku wschodniego.

Najbardziej uniwersalnym podziałem tego typu zgromadzeń wyposażonych w kompetencje władzy ustawodawczej jest rozdzielenie ich według liczby izb, z których się składają. Współcześnie według tego kryterium można wyróżnić parlamenty jedno- i dwuizbowe. W ostatnich kilkudziesięciu latach, mimo gwałtownego rozwoju idei państwa prawnego i demokratyzacji systemów politycznych, model bikameralizmu cieszy się coraz mniejszą popularnością. Również w Polsce toczy się dyskusja nad sensem istnienia Senatu zwanego niekiedy ,izbą refleksji i zadumy"'. W duchu rozwiązań skandynawskich już w 2004 roku działacze Platformy Obywatelskiej zadeklarowali chęć likwidacji tego gremium (Akcja $4 \times$ TAK), co rozpoczęło publiczną debatę trwającą do dziś ${ }^{2}$. Jednakże aby kompleksowo rozważyć zalety i wady takiego rozwiązania, należy odwołać się do regulacji prawnych innych państw, których doświadczenie może okazać się szczególnie cenne.

${ }^{1}$ Marszałek Karczewski: Senat to izba refleksji i zadumy, http://telewizjarepublika.pl/marszalek-karczewski-senat-to-izba-refleksji-i-zadumy,43849.html (dostęp: 18.06.2020).

2 P. Wroński, Po co PO $4 \times$ TAK, http://wyborcza.pl/1,76842,2417025.html?disableRedirects=true (dostęp: 18.06.2020). 


\section{Krótka historia parlamentaryzmu}

Początków parlamentaryzmu można doszukiwać się już w X wieku, gdyż w 930 roku ukształtował się islandzki Althing obradujący niekiedy z kilkudziesięcioletnimi przerwami aż do teraz ${ }^{3}$. Wywodzący się z instytucji tingu, czyli zgromadzenia mężczyzn charakterystycznego dla plemion germańskich, miał kompetencje prawodawcze oraz sądownicze ${ }^{4}$. Innym, równie odległym przykładem jest zjazd lenników i dworzan tworzących radę zwaną Hoftagiem, zwoływaną na terenie dzisiejszych Niemiec. W 1489 roku przekształciła się ona w składający się z trzech kurii (elektorów, książąt, miast) Sejm Rzeszy istniejący aż do 1806 roku ${ }^{5}$. Mimo wskazanych przykładów fundamentalny wpływ na konstruowanie się doktryny parlamentaryzmu w Europie, a później w Ameryce Północnej, miały doświadczenia angielskie, w ramach których zostały wykreowane pierwsze gremia ,idealne” złożone nie tylko z podmiotów nominowanych bezpośrednio przez władcę. Należy zauważyć, że już w 1215 roku na mocy art. 15 Magna Charta Libertatum król zobowiązywał się zwoływać w odpowiednim składzie Radę Królewską przekształconą w 1264 roku za sprawą działalności Szymona z Montfort w stałą instytucję zwaną parlamentem, od XIV wieku składającą się z dwóch izb 6 . Początkowo kompetencje nowo powstałego ciała ograniczały się do udzielania zgody na wprowadzenie nowych podatków oraz wnoszenia petycji. Zostały one jednak rozszerzone już kilkadziesiąt lat później — w 1341 roku ukonstytuowała się zasada, według której do ustanowienia nowych praw oprócz zgody królewskiej potrzeba było również upoważnienia parlamentu. Swoistym kamieniem milowym w kształtowaniu się nowoczesnego parlamentaryzmu było wprowadzenie w 1429 roku wyborów do późniejszej Izby Gmin, opartych na cenzusie majątkowym, oraz pozostawienie królowi prawa nominacji do Izby Lordów. Po siedemnastowiecznej wojnie domowej i cromwellowskiej Republice Angielskiej te proste według dzisiejszego mniemania zasady, umocnione następnie innymi aktami o charakterze konstytucyjnym (Habeas Corpus Act, Bill of Rights, Act of Settlement), pozwoliły utworzyć pierwszą na świecie monarchię parlamentarną będącą wzorem dla innych europejskich mocarstw $\mathrm{w}$ dobie masywnych przemian epoki oświecenia. Jej owocem było powstanie składających się z jednej lub dwóch izb, najwyższych organów ustawodawczych w Stanach Zjednoczonych Ameryki (1789) czy Francji (1791), będących ucieleśnieniem idei Jean-Jacques’a Rousseau i Monteskiusza.

${ }^{3}$ H. Binkowski, Althing - najstarszy parlament w Europie, http://www.islandia.org.pl/althing. html (dostęp: 18.06.2020).

4 Ting, [w:] Encyklopedia powszechna PWN, https://encyklopedia.pwn.pl/haslo/ting;3987418. html (dostęp: 18.06.2020).

5 A. Dziadzio, Powszechna historia prawa, Warszawa 2012, s. 82.

6 R.H. Helmholz, Magna Carta and the ius commune, „University of Chicago Law Review” 66, 1999, nr 2. 
Recepcja wzorców napoleońskich, w tym prawa, doprowadziła do oktrojowania aktów konstytucyjnych przez wielu władców ówczesnej Europy, szczególnie na terenach dzisiejszych Niemiec. Jednakże tylko część z nich nawiązywała do zasady reprezentacji, tworząc parlamenty złożone $\mathrm{z}$ dwóch izb, co było podejściem pragmatycznym, gdyż system monokameralny byłby niebezpieczny dla monarchicznej formy rządów ${ }^{7}$. Monteskiuszowska zasada podziału, zgodnie z dzisiejszym rozumieniem, była odrzucana, a parlamentom przyznawano bardzo ograniczone kompetencje ustawodawcze. Począwszy jednak od Wiosny Ludów aż po drugą połowę XX wieku liczba spraw oddana pod kognicję gremiów będących najistotniejszym organem władzy ustawodawczej systematycznie rosła, doprowadzając niekiedy do preponderancji parlamentu i powstania systemów parlamentarno-gabinetowych.

\section{Egzystencja parlamentu a realna demokracja}

Podstawową instytucją państw charakteryzujących się demokratycznym systemem rządów jest parlament, który zgodnie z zasadą zwierzchnictwa narodu i reprezentacji pośredniej powinien w swych rękach skupiać najważniejsze kompetencje władzy ustawodawczej. Z całą pewnością należy stwierdzić, że instytucja ta jest warunkiem sine qua non istnienia demokratycznego państwa prawnego, jednakże nie jest to okoliczność wystarczająca ${ }^{8}$. Współcześnie, podobnie jak w XIX i XX wieku, zgromadzenia narodowe w wielu suwerennych republikach pełnią jedynie pozornie funkcję organu tworzącego prawo, stanowiąc instytucję wyłącznie fasadową, za którą kryje się forma rządów autorytarnych, a nawet totalitarnych. Nie można przecież twierdzić, że istniejące na mocy rozdziału szóstego konstytucji z 2009 roku, liczące 687 deputowanych, Najwyższe Zgromadzenie Ludowe Koreańskiej Republiki Ludowo-Demokratycznej jest tworem całkowicie niezależnym reprezentującym poglądy społeczeństwa ${ }^{9}$. Prócz istnienia samej instytucji relewantne i zarazem obowiązkowe jest zagwarantowanie parlamentowi odpowiednich kompetencji, ukształtowanie systemu wyborczego zgodnie z zasadami równości, bezpośredniości i powszechności oraz zapewnienie mu odpowiedniej niezależności od innych władz państwa. Brak któregoś z tych elementów wyklucza możliwość istnienia państwa w pełni demokratycznego, czego współczesnym przykładem mogą być sułtańskie państwa Bliskiego Wschodu. Przykładowo w pustynnym Kuwejcie mimo funkcjonowania jednoizbowego Zgromadzenia Narodowego i materialnej konstytucji wprowadzony został zakaz istnienia partii

7 A. Dziadzio, Koncepcja państwa prawa w XIX w. Idea a rzeczywistość, „Czasopismo Prawno-Historyczne" 62, 2005, s. 183.

8 A. Antoszewski, Władza ustawodawcza, [w:] Systemy polityczne współczesnej Europy, red. A. Antoszewski, R. Herbut, Warszawa 2007, s. 222.

9 The Socialist Constitution of the Democratic People's Republic of Korea, http://www.naenara.com.kp/en/politics (dostęp: 18.06.2020). 
politycznych ${ }^{10}$. Nastawiony na likwidację opozycji i betonowanie obecnego monarchicznego ładu system, bardzo podobny do ustroju Zjednoczonych Emiratów Arabskich, może być uznany jedynie za fasadowy, nawiązujący bardziej do idei izb działających na podstawie oktrojowanych konstytucji pierwszej połowy wieku XIX, a nie współczesnego, rozwiniętego gospodarczo i ekonomicznie państwa.

Egzystowanie wadliwych instytucji parlamentarnych nie jest ograniczone wyłącznie do małych państw, czego wyrazem może być funkcja i sposób wyboru przedstawicieli, utworzonego w 1954 roku Ogólnochińskiego Zgromadzenia Przedstawicieli Ludowych, do którego według art. 58 konstytucji należy najwyższa władza ustawodawcza ${ }^{11}$. Niejasność wieloetapowej elekcji, zależność od Stałego Komitetu Biura Politycznego ChRL oraz niewielkie, rozmyte kompetencje czynią z tego wyjątkowo dużego gremium, liczącego tradycyjnie maksymalnie 3 tysiące deputowanych, ciało fasadowe, legalizujące narzucone przez Komunistyczną Partię Chin rozwiązania ${ }^{12}$.

Opracowywany od 2006 roku przez Economist Intelligence Unit wskaźnik demokracji jednoznacznie ukazuje, że samo istnienie domniemanego najwyższego organu władzy ustawodawczej nie implikuje istnienia nie tylko dojrzałej, lecz nawet jakiejkolwiek formy demokracji. Według przeprowadzonego w 2018 roku badania aż 51 z wszystkich 167 badanych państw określanych jest jako „reżim autorytarny", a w 50 z nich (oprócz Arabii Saudyjskiej) istnieją konstytucyjne parlamenty lub nazywane nimi ciała doradcze. Instytucje takie nie spełniają podstawowych zadań związanych ze stanowieniem prawa i kontrolą władzy ustawodawczej. Deputowani są w nich wybierani zwykle na podstawie niejasnego i pozbawionego równości systemu wyborczego, który rzeczywiście przypomina proces nominacji, a nie realizację zasady reprezentacji politycznej społeczeństwa. Bardzo niepokojące wydaje się, że jedynie 76 suwerennych państw jest uznawanych za demokrację pełną lub wadliwą ${ }^{13}$.

\section{Rodzaje parlamentów ze względu na liczbę izb}

Najbardziej uniwersalnym, najprostszym i dzięki temu najczęściej wykorzystywanym podziałem najważniejszych instytucji władzy ustawodawczej jest kryterium liczby izb składających się na parlament. Historia pokazuje, że państwa przyjmowały najróżniejsze rozwiązania dotyczące organizacji wewnętrz-

10 Kuwejt. Ustrój polityczny, [w:] Encyklopedia powszechna PWN, https://encyklopedia.pwn. pl/haslo/Kuwejt-Ustroj-polityczny;4574593.html (dostęp: 18.06.2020).

11 Constitution of the People's Republic of China, http://www.npc.gov.cn/zgrdw/englishnpc/ Constitution/2007-11/15/content_1372965.html (dostęp: 18.06.2020).

12 M. Dargas, Wjakim kierunku zmierza prawo Chińskiej Republiki Ludowej — ku systemowi common law czy ku kompleksowej kodyfikacji prawa?, „Gdańskie Studia Azji Wschodniej” 1, 2012, s. 59-68.

13 Democracy Index 2017, https://www.eiu.com/topic/democracy-index (dostęp: 18.06.2020). 
nej i struktury tego ciała — od systemów jednoizbowych po multikameralne skończywszy. Islandzki Althing składający się z Lögrétty i sądu najwyższego (fimmtardómur) tworzył system quasi-dwuizbowy ${ }^{14}$, podczas gdy Sejm Rzeszy w 1489 roku był złożony z trzech kurii: elektorów, książąt i miast, z tym że ostatnia z nich do 1582 roku miała charakter wyłącznie głosu doradczego ${ }^{15}$. Szwedzki Riksdag zmieniał swe oblicze wielokrotnie (miał od aż sześciu do jednej izby); formalnie od 1527 roku, jako Ståndsriksdagen, aż do drugiej połowy XIX wieku obradował jako parlament stanowy, składający się z reprezentacji czterech stanów, przekształcając się następnie w organ dwu-, a od 1969 roku jednoizbowy ${ }^{16}$. Trikameralizm zaś występował we francuskich Stanach Generalnych oraz — od 1984 aż do zniesienia apartheidu w 1994 roku — w Republice Południowej Afryki ${ }^{17}$.

Analiza historyczna pozwala na wywnioskowanie, że systematycznie zmniejsza się liczba izb w parlamencie. Począwszy od średniowiecznych systemów stanowych, przez systemy bikameralne pierwszej połowy XIX wieku państw niemieckich (Bawaria - 1818, Wirtembergia - 1819), mające za cel potrzymanie monarchii, aż do czasów współczesnych liczba parlamentów jednoizbowych stale wzrasta $^{18}$. Według przygotowanego przez Unię Międzyparlamentarną raportu z 2012 roku 190 państw na 193 ma organ pełniący funkcję ustawodawczą, będący parlamentem lub organem do niego podobnym. Aż $113 \mathrm{z}$ nich funkcjonuje w systemie unikameralnym, natomiast pozostałe, stanowiące ponad $40 \%$ wszystkich zgromadzeń parlamentarnych, to organy dwuizbowe ${ }^{19}$. Należy przy tym zauważyć, że nie ma żadnej prawidłowości, która nieomylnie wskazywałaby, iż państwa w pełni demokratyczne mają całkowicie inne zasady funkcjonowania tej instytucji aniżeli podmioty charakteryzujące się autorytarnym sposobem sprawowania władzy. Podobnie wielkość państwa, mierzona liczbą ludności tudzież rozległością terytorium, nie pozwala jednoznacznie ustalić, czy mamy do czynienia z systemem parlamentarnym opartym na działalności jednej czy dwóch izb. Najbliższe prawdy, z pewnymi wyjątkami, jest twierdzenie, że państwa o strukturze federacyjnej mają dwuizbowe zgromadzenia narodowe.

Całkowicie odmiennie prezentuje się próba zbudowania podobnej zasady na podstawie rozmieszczenia geograficznego poszczególnych krajów. Parlamenty unikameralne dominują w Skandynawii, byłych republikach nadbałtyckich, Ocea-

14 M. Koszowski, Medieval Iceland: The influence of culture and tradition on law, „Scandinavian Studies" 86, 2014, nr 3, s. 333-351.

15 A. Dziadzio, Powszechna..., s. 82.

${ }^{16}$ Riksdagens historia, http://www.riksdagen.se/sv/sa-funkar-riksdagen/demokrati/riksdagens-historia/ (dostęp: 18.06.2020).

17 R.B. Mattes, South Africa: Democracy without the people?, „Journal of Democracy” 13, 2002, nr 1, s. 22-36.

18 A. Dziadzio, Koncepcja..., s. 182.

19 Global parliamentary report. The changing nature of parliamentary representation, http:// archive.ipu.org/pdf/publications/gpr2012-full-e.pdf (dostęp: 18.06.2020). 
nii, Afryce Subsaharyjskiej oraz państwach Bliskiego Wschodu. Procentowo mają największy udział na wyspach znajdujących się na Pacyfiku i krajach kontynentu afrykańskiego. Warto również zwrócić uwagę na wniosek wynikający z badań Kazimierza Polarczyka, które wskazują na większą częstotliwość występowania parlamentów wieloizbowych w państwach rozwijających się aniżeli rozwiniętych $^{20}$. To bardzo interesujące spostrzeżenie, szczególnie zważywszy, że według Economist Intelligence Unit 9 na 20 państw „demokracji pełnej” to właśnie systemy oparte na jednoizbowej władzy ustawodawczej.

Prawdziwy renesans unikameralizmu zaczął się w drugiej połowie XX wieku, kiedy Nowa Zelandia (1951), Dania (1953) oraz Szwecja (1970) zdecydowały się na parlament jednoizbowy. Za tą tendencją podążyło wiele państw bloku socjalistycznego w Europie, do których należy przykładowo zaliczyć kraje bałtyckie, Węgry, Bułgarię, Słowację, Mołdawię i Ukrainęę ${ }^{21}$ Istniejący ponadto ówcześnie fenomen dekolonializacji i wiążące się z nim powstanie wielkiej liczby nowych podmiotów gwałtownie zwiększyło liczbę systemów bikameralnych na świecie, szczególnie w obrębie tak zwanej Czarnej Afryki oraz Oceanii.

Starszy historycznie bikameralizm przeważa w wysoko rozwiniętych państwach Europy oraz, nie licząc Wysp Karaibskich stanowiących swoistą mozaikę systemów, w obu Amerykach. Ponad połowa członków Organizacji Współpracy Gospodarczej i Rozwoju (OECD) oraz państwa należące do G7 (do 2014 roku G8) to kraje z strukturą dwuizbowych parlamentów, co może potwierdzać tezę Kazimierza Polarczyka ${ }^{22}$. Nie bez wątpliwości można stwierdzić, że parlament oparty na współdziałaniu dwóch ciał jest charakterystyczny dla podmiotów mających bogatą, demokratyczną tradycję zbudowaną jeszcze na przełomie XIX i XX wie$\mathrm{ku}$. Bezsprzecznie do tego zaszczytnego grona należą Stany Zjednoczone, Wielka Brytania oraz Francja.

W państwach federalnych charakterystyczne jest występowanie systemu bikameralnego będącego relewantnym elementem ustroju takich podmiotów, jak Argentyna, Australia, Belgia, Brazylia, Etiopia, Kanada, Niemcy, Rosja czy Szwajcaria. Pozwala on, dzięki istnieniu dwóch izb parlamentu, zbudować wyjątkowy mechanizm, w którym możliwe jest połączenie reprezentacji całego narodu i poszczególnych podmiotów tworzących federację. Bardzo podobna struktura występuje w unitarnych państwach quasi-federalnych, takich jak Zjednoczone Królestwo i Hiszpania, w których istnieją silne tendencje i dążenia separatystyczne

${ }^{20}$ K. Polarczyk, Parlament polski na tle parlamentów innych państw. Analiza statystyczna, „Biuro Studiów i Ekspertyz” 214, 2003, s. 32, http://biurose.sejm.gov.pl/teksty_pdf_03/r-214.pdf (dostęp: 18.06.2020).

${ }^{21}$ R. Klepka, Zasady funkcjonowania parlamentu dwuizbowego $w$ demokratycznym państwie unitarnym - przypadek Polski, s. 7, https://www.academia.edu/16436104/Zasadność_funkcjono wania_parlamentu_dwuizbowego_w_demokratycznym_państwie_unitarnym_przypadek_Polski (dostęp: 18.06.2020).

${ }^{22}$ K. Polarczyk, op. cit., s. 32. 
oraz konflikty między władzą lokalną a centralną ${ }^{23}$. Modelowym przykładem takiego stanu są dwuizbowe Kortezy Generalne, w których 208 członków Senatu jest wybieranych w większościowych wyborach, a 58 nominowanych jest przez parlamenty wspólnot autonomicznych.

Na samym końcu należy zwrócić uwagę, że izby wyższe liczą mniej członków niż niższe. Wyjątkiem jest parlament Zjednoczonego Królestwa, w którym aktualnie zasiada 800 parów duchownych i świeckich oraz 650 członków Izby Gmin. Inne państwa, zbudowane w oparciu na zasadach systemu bikameralnego, niezależnie od ich geograficznego położenia wykazują odwrotne proporcje. Konstytucja Belgii z 1831 roku w art. 63 i art. 67 ustala liczbę Izby Reprezentantów i Senatu na 150 i odpowiednio 71 członków. Brazylijski Kongres Narodowy liczy 513 posłów i 81 senatorów, natomiast indyjskie Rajya Sabha (Izba Stanów) i Lok Sabha (Izba Ludowa) — maksymalnie 552 i 250 deputowanych $^{24}$.

\section{Krótka historia wyższej izby polskiego parlamentu}

Trywializmem jest stwierdzenie, że w Rzeczypospolitej Polskiej parlament składa się z dwóch izb: Sejmu i Senatu. Druga z nich, zniesiona w 1946 roku na podstawie sfałszowanego referendum ludowego, została przywrócona na mocy umów okrągłostołowych ponad czterdzieści lat później. Bardzo bogata historia parlamentaryzmu Królestwa Polskiego, a następnie Rzeczypospolitej Obojga Narodów zawsze była związana z osobami szczególnie istotnymi dla władzy monarszej. Przyszła izba wyższa wyłoniła się na przełomie XIV i XV wieku z rady królewskiej stanowiącej niegdyś ciało doradcze króla. Zgodnie z przełomowymi badaniami Wacława Uruszczaka już w 1468 roku w trakcie pierwszego Sejmu walnego stała się ona ,jednym z stanów sejmujących" 25 . Oficjalnie jej relewantny status ukształtował akt zgromadzenia radomskiego z 1505 roku, potocznie znany jako konstytucja Nihil novi. Pozycja Senatu została znacząco zwiększona w momencie powołania do życia, na mocy artykułów henrykowskich, stałej rady 16 senatorów-rezydentów, z których czterech miało być obecnych stale przy królu, natomiast od 1607 roku gremium to miało kompetencje wydawania wiążących rad zwanych Senatus consulta ${ }^{26}$. W czasach oligarchii magnackiej z powodu niemożności funkcjonowania parlamentu to właśnie Senat podejmował najważniejsze decyzje w państwie ${ }^{27}$.

23 R. Klepka, op. cit., s. 8.

24 Parliament of India. Lok Sabha. House of the People, https://loksabha.nic.in (dostęp: 18.06. 2020).

25 W. Uruszczak, Historia państwa i prawa polskiego, t. 1. 966-1795, Warszawa 2010, s. 137.

26 Ibidem, s. 231.

27 M. Markiewicz, Rzeczpospolita bez sejmu. Funkcjonowanie państwa, [w:] Między barokiem a oświeceniem, Olsztyn 1996, s. 177. 
Znaczne zmiany w funkcjonowaniu parlamentu wprowadziła ustawa rządowa z 3 maja, wyjątkowo ograniczając możliwości kreacyjne izby wyższej przez pozbawienie jej inicjatywy ustawodawczej. Wyposażony w prawo veta zawieszającego Senat nie odegrał jednak większej roli w kształtowaniu ustroju Rzeczypospolitej Obojga Narodów z powodu szybkiego upadku zarówno najważniejszego aktu, jak i samego państwa. Nie był to jednak koniec dziejów tego immanentnego dla politycznego systemu Polski organu, gdyż już kilkanaście lat później, w 1807 roku, na mocy oktrojowanej przez Napoleona konstytucji, ponownie stał się on jedną z izb Sejmu Księstwa Warszawskiego ${ }^{28}$. Podtrzymano jednak wyraźnie wprowadzony ustawą zasadniczą z 1791 roku system zwany dziś bikameralizmem asymetrycznym, charakteryzujący się koncentracją głównej funkcji ustawodawczej w izbie niższej, przekazując jej większość prawodawczych kompetencji. Model ten, istniejący współcześnie w przytłaczającej większości państw opierających się na funkcjonowaniu dwuizbowych parlamentów, występował w konstytucji Królestwa Polskiego, marcowej i kwietniowej. Należy zwrócić uwagę na pewną prawidłowość, zgodnie z którą w wypadku utraty przez Rzeczpospolitą suwerenności organ ten zawsze był likwidowany, na co zwrócił uwagę Andrzej Duda, otwierając pierwsze posiedzenie Senatu IX kadencji ${ }^{29}$.

W 1989 roku, po ponad czterdziestoletniej nieobecności, na podstawie okrągłostołowych porozumień ponownie w polskim systemie parlamentarnym pojawiła się instytucja Senatu zdominowana wówczas przez przedstawicieli Komitetu Obywatelskiego „Solidarność”. Jej pozycja została przy tym odpowiednio ugruntowana przez małą konstytucję z 1992 roku oraz współcześnie obowiązującą ustawę zasadniczą.

Na szczególne uwzględnienie zasługuje zasiadanie w tym gremium osobistości związanych z najważniejszymi urzędami ówczesnego państwa. Początkowo członkami rady królewskiej, a następnie Senatu zostawali dygnitarze piastujący funkcję wojewodów, kasztelanów większych, mniejszych i konarskich — w ściśle ustalonej precedencji. Nie należy przy tym zapominać o relewantnym statusie duchownych katolickich, albowiem na czele izby stał arcybiskup Gniezna, pełniący zarazem funkcję prymasowską ${ }^{30}$. Pomimo zmian ustrojowych i związanych z liczebnością status osób zajmujących miejsce w izbie wyższej nie podlegał istotnym zmianom. Według art. 23 ustawy konstytucyjnej Księstwa Warszawskiego z 1807 roku skład gremium tworzyło po sześciu biskupów, wojewodów

28 M. Kallas, M. Krzymkowski, Historia ustroju i prawa w Polsce 1772/1795-1918. Wybór źródet, Warszawa 2006, s. 51-52.

29 „Senat jest symbolem wolnej, suwerennej i niepodlegtej Polski”. Prezydent Duda otwiera posiedzenie izby wyższej parlamentu, https://wpolityce.pl/polityka/271569-senat-jest-symbolem-wolnej-suwerennej-i-niepodleglej-polski-prezydent-duda-otwiera-posiedzenie-izby-wyzszej-parlamentu-przemowienie (dostęp: 18.06.2020).

30 E. Opaliński, Sejm srebrnego wieku, 1587-1652, Warszawa 2001, s. 25. 
oraz kasztelanów ${ }^{31}$; symetryczne regulacje znalazły się w ustawie konstytucyjnej Królestwa Polskiego z 1815 roku, aczkolwiek dodano jeszcze książąt krwi ${ }^{32}$. Ze swoistym kreowaniem, z mocy prawa, członków izby wyższej ze względu na pełnioną funkcję skończyła ustawa z dnia 17 marca 1921 roku, zwana potocznie konstytucją marcową. Zasadniczy dla Senatu art. 36 ograniczał jednak prawo wybierana przez wprowadzenie cenzusu domicylu oraz podwyższenie wieku wyborców do 30 lat, ustanawiając zarazem konieczność ukończenia 40. roku życia w zakresie biernego prawa wyborczego ${ }^{33}$. Utrzymanie wymagań w przedmiocie osiągnięcia odpowiedniego wieku (art. 99 ust. 2) przez kandydatów na senatorów jest uzasadniane dążeniem do utworzenia gremium, którego członkowie mają większe doświadczenie społeczne i zawodowe ${ }^{34}$.

\section{Czy w Polsce izba wyższa rzeczywiście jest potrzebna?}

Jak już wspomniano, współcześnie większość państw działania władzy ustawodawczej opiera na parlamentach składających się z jednej izby. Ponadto w ostatnich kilkudziesięciu latach obserwuje się zjawisko odchodzenia od systemu bikameralnego. Rodzi to ciągłe dyskusje dotyczące potrzeby funkcjonowania Senatu, który dzisiaj wydaje się jedynie sztucznym tworem bez istotnego wpływu na kształtowanie aktów prawnych.

Istnienie dwuizbowego parlamentu niesie z sobą wiele istotnych problemów wewnętrznych, które dotyczą zwłaszcza relacji poszczególnych gremiów względem siebie. W dziewiętnastowiecznej Europie izbę wyższą tworzyli przedstawiciele arystokracji, a niższą — reprezentanci średnich warstw społecznych ${ }^{35}$. Dziś z powodu zmian społecznych i rozkwitu idei demokracji przedstawicielskiej taka struktura spotykana jest wyjątkowo. Współcześnie nauka opracowała kilka innych, podstawowych rozwiązań, do których należą modele:

— izby reprezentującej kraje federalne,

- izby typu islandzkiego (nordyckiego),

— izby samorządowej,

— izby refleksji i rozwagi ${ }^{36}$.

Pierwsze z rozwiązań funkcjonuje wyłącznie w państwach o ustroju federalnym. Podstawowym celem istnienia w tym modelu dwuizbowego parlamentu jest chęć zagwarantowania prawa reprezentacji nie tylko ogółowi społeczeństwa, lecz także poszczególnym krajom związkowym, których interesy przez swoje

31 M. Kallas, M. Krzymkowski, op. cit., s. 51.

32 Ibidem, s. 105.

33 Dz.U. Nr 44, poz. 267.

34 P. Radziewicz, Komentarz do artykułu 99, [w:] Konstytucja Rzeczypospolitej Polskiej. Komentarz, red. P. Tuleja, Warszawa 2019, s. 315.

35 A. Dziadzio, Koncepcja..., s. 183.

36 R. Klepka, op. cit., s. 14. 
niewielkie rozmiary mogłyby być niekiedy bagatelizowane lub pomijane na forum całej wspólnoty. Idealnym przykładem ilustrującym te zależności jest ustrój Stanów Zjednoczonych, w których najmniej ludny stan Wyoming (około 580 tysięcy mieszkańców) jest reprezentowany przez taką samą liczbę senatorów co najludniejsza Kalifornia (blisko 40 milionów ludzi) ${ }^{37}$. Warto zaznaczyć, że nie w każdym państwie podzielonym na stany, prowincje, kantony czy okręgi istnieje przedstawione rozwiązanie zakładające rozdzielenie funkcji „po równo” pomiędzy obie izby, jak ma to miejsce w Belgii czy Szwajcarii - co występuje przykładowo w austriackiej Radzie Federalnej, której wątłe uprawnienia są charakterystyczne dla modelu izby refleksji i rozwagi ${ }^{38}$. Istnieją ponadto federacje, takie jak Wenezuela czy Mikronezja, których parlament składa się wyłącznie z jednej izby ${ }^{39}$.

Izba typu islandzkiego, zwana dziś bardziej prawidłowo nordycką lub jednoizbowością złożoną, to model charakterystyczny niegdyś właśnie dla Islandii (do 1991) oraz Norwegii (do 2009 roku). Istotą tego systemu był podział wewnętrzny jednoizbowego parlamentu na dwie grupy, mający znaczenie dla procesu ustawodawczego. Mniej liczne gremium przyjmowało, odrzucało tudzież zwracało ciału liczniejszemu projekty ustaw ${ }^{40}$. Dominacja partii politycznych w walce o głosy wyborców doprowadziła do zrodzenia się pomysłu powołania, w formie drugiej izby parlamentu, reprezentacji o charakterze niepolitycznym, zwanej niekiedy izbą samorządową lub reprezentacją funkcjonalną ${ }^{41}$. To rozwiązanie nie jest zbyt rozpowszechnione na świecie i działa jedynie w Republice Irlandii, w której wybory do izby wyższej (Seanad Éireann) odbywają się w bardzo specyficzny sposób - 11 członków senatu nominowanych jest przez premiera, 2 wybieranych przez absolwentów Trinity College i National University of Ireland, a 43 przez ciała elektorskie. Utworzony w ten sposób organ składa się ze specjalistów w swoich dziedzinach, co pozwala dokapitalizować proces ustawodawczy wiedzą. Nazwa „izba samorządowa” oznacza jeden z modeli reprezentacji funkcjonalnej, która miałaby składać się z przedstawicieli wspólnot samorządowych o terytorialnym lub gospodarczym charakterze.

37 Population Distribution by Citizenship Status, https://www.kff.org/other/state-indicator/ distribution-by-citizenship-status/?dataView $=1 \&$ currentTimeframe $=0 \&$ sortModel $=\% 7 \mathrm{~B}$ (dostęp: 18.06.2020).

38 The responsibilities of the Federal Council, https:/www.parlament.gv.at/ENGL/PERK/ NRBRBV/BR/AUFGBR/index.shtml (dostęp: 18.06.2020).

39 Wenezuela. Ustrój polityczny, [w:] Encyklopedia powszechna PWN, https://encyklopedia. pwn.pl/haslo/Wenezuela-Ustroj-polityczny;4575675.html (dostęp: 18.06.2020).

40 B.E. Rasch, Electoral systems, parliamentary committees, and party discipline: The Norwegian storting in a comparative perspective, [w:] Party Discipline and Parliamentary Government, Columbus 1999, s. 133.

41 P. Czarny, Problem zasadności istnienia dwuizbowego parlamentu w Polsce, [w:] Prawo konstytucyjne RP, red. P. Sarnecki, Warszawa, s. 231-232. 
Ostatni z wskazanych modeli, zwany izbą refleksji i rozwagi, jest elementem charakterystycznym dla państw unitarnych. Podstawowym założeniem istnienia drugiej izby parlamentu jest chęć dokładniejszego, głębszego i bardziej starannego przeanalizowania projektów ustaw oraz konsekwencji, jakie ich uchwalenie może przynieść. Idea wywodząca się z zasady podziału władzy Monteskiusza, nawiązująca do systemu kontroli i wzajemnego hamowania, jest dziś mocno krytykowana nie tylko w Polsce, lecz także w innych krajach. Wzorem może być Chorwacja, która na mocy nowelizacji konstytucji w 2001 roku odeszła od modelu bikameralnego i zlikwidowała Izbę Żupanii będącą odpowiednikiem polskiego Senatu $^{42}$. Mimo znakomitych podstaw teoretycznych wprowadzenie tudzież jej istnienie w państwach, w których kandydaci do izby wyższej są ściśle związani $\mathrm{z}$ organizacjami politycznymi, nie ma — zgodnie z historią ostatnich kilkunastu lat — większego znaczenia.

Przykład Rzeczypospolitej, w której od wyborów przeprowadzonych w 1991 roku systematycznie ugrupowanie odnoszące zwycięstwo w Sejmie triumfowało również w izbie wyższej, jednoznacznie wskazuje, że system ten doprowadza jedynie do sztucznego zwiększenia liczby parlamentarzystów. Stu senatorów wywodzących się w większości z partii dzierżącej władzę analizuje projekt, który wcześniej był procedowany i uchwalony przez deputowanych, którzy należą do tego samego środowiska politycznego. Odwołując się do statystyk, warto zwrócić uwagę na działalność Senatu IX kadencji, który do 5 listopada 2018 roku rozpatrzył łącznie 662 ustawy, do 162 wprowadzając poprawki, nie odrzucając natomiast żadnej z nich ${ }^{43}$. W latach poprzednich, przykładowo 2001-2005 oraz 2005-2007, druga izba polskiego parlamentu na 1265 i 708 projektów ustaw podjęła uchwałę o odrzuceniu odpowiednio 6 i 4 z nich ${ }^{44}$. System ten, przynajmniej według matematycznych rozważań, nie spełnia więc swojego podstawowego zadania, jakim jest dopracowanie aktów normatywnych przed ich wejściem w życie, dlatego zdecydowanie lepszym rozwiązaniem byłoby utworzenie mniej licznej izby profesjonalnej opierającej się na doświadczeniach modelu reprezentacji funkcjonalnej. Ponadto istotnym argumentem ekonomicznym podnoszonym przez zwolenników likwidacji izby wyższej jest możliwość zaoszczędzenia znacznej kwoty, gdyż wydatki Kancelarii Senatu w 2017 roku wynosiły ponad 169 milionów złotych, a fundusz ten można by lepiej zagospodarować ${ }^{45}$.

42 K. Składowski, Izba Żupanii jako element systemu konstytucyjnego w Republice Chorwacji, „Przegląd Prawa Konstytucyjnego” 2010, nr 2-3, s. 148.

${ }^{43}$ Podstawowe dane statystyczne o pracy Senatu IX kadencji, Biuro Analiz, Dokumentacji i Korespondencji Kancelarii Senatu, https://www.senat.gov.pl/gfx/senat/userfiles/_public/k8/statystyki/podstawowe_dane_9/01_podstawowe_statystyki.pdf (dostęp: 18.06.2020).

44 R. Klepka, op. cit., s. 15.

45 Sprawozdanie z wykonania budżetu państwa za okres od 1 stycznia do 31 grudnia 2017 r. (druk $n r$ 2559), t. 1, http://orka.sejm.gov.pl/Druki8ka.nsf/0/42EEAAA67DED2F09C125829D002E C6C1/\%24File/2559-Tom-I.pdf (dostęp: 18.06.2020). 
Bardzo trudno znaleźć racjonalne powody istnienia dwuizbowego parlamentu w państwie jednolitym. Szczególnie system Rzeczypospolitej oparty na modelu izby rozwagi i refleksji, swoiście „spajający” oba gremia równym czasem trwania kadencji, politycznym charakterem, możliwością przełamania veta izby wyższej przez Sejm oraz niekiedy „sztucznym” wydłużeniem procesu legislacyjnego, nie jest przykładem efektywnie działającej doktryny parlamentaryzmu bikameralnego. Istnieje jednak duża grupa zwolenników utrzymania Senatu, odwołująca się głównie do tradycji historycznej i argumentów natury aksjologicznej ${ }^{46}$. Zlikwidowanie tego organu mogłoby przywołać na myśl czasy komunistycznego reżimu oraz carskiego zniewolenia charakterystycznego dla drugiej połowy XIX wieku. Ponadto, zgodnie z art. 235 ustawy zasadniczej do wprowadzenia jednoizbowej legislatywy, a nawet do zredukowania liczebności izby wyższej potrzebna jest kwalifikowana zgoda Sejmu oraz bezwzględna Senatu. Większość taka, szczególnie w aktualnym stanie politycznym, byłaby do osiągnięcia, ale z przyczyn zarówno partyjnych, jak i czysto pragmatycznych jest to raczej niemożliwe. Idea samoograniczenia się władzy, jakkolwiek bardzo atrakcyjna dla obywateli, wymagałaby od parlamentarzystów niebywałej konsekwencji i chęci zbudowania systemu od nowa, czego dziś grupie rządzącej brakuje. Bez tej chęci nie uda się bowiem, pomimo istnienia relewantnych argumentów, zmienić struktury i zracjonalizować parlamentu Rzeczypospolitej Polskiej.

Zaprezentowane stwierdzenia, jakże symptomatyczne dla istnienia w III RP izby wyższej polskiego parlamentu, włącznie z Senatem IX kadencji (i szczególnie dla niego), nabrały istotnie innego znaczenia po zebraniu się na pierwszym posiedzeniu w dniach 12 i 13 listopada 2019 roku gremium o nowym składzie osobowym. Należy bowiem zaznaczyć, że w wyniku wyborów spolaryzowana opozycja uzyskała bezwzględną większość; senatorowie reprezentujący Komitet Wyborczy Prawo i Sprawiedliwość uzyskali 48 mandatów ${ }^{47}$. Doprowadziło to do zrodzenia rozłamu w obrębie władzy ustawodawczej, podobnego do znanego z egzekutywy pojęcia koabitacji ${ }^{48}$. Ze względu na niezwykle wyraźne różnice polityczne konsekwencją szorstkiej współpracy obu izb, spotęgowanej w szczególności stanem epidemii wirusa SARS-CoV-2 i wprowadzeniem przez Radę Ministrów wątpliwych co do zgodności z normami powszechnie obowiązującego prawa restrykcji społeczno-gospodarczych ${ }^{49}$, stała się wzmożona aktywność

46 Karczewski: Senat będzie izba refleksji i zadumy, http://www.polsatnews.pl/wiadomosc/2016-01-03/karczewski-senat-bedzie-izba-refleksji-i-zadumy (dostęp: 18.06.2020).

47 Dz.U. poz. 1956.

48 Koabitacja (fr. cohabitation - współzamieszkiwanie) ma miejsce w wypadku zaistnienia w obrębie władzy wykonawczej sytuacji, w której prezydent pochodzi z odmiennej orientacji politycznej aniżeli członkowie rządu, w tym premier. Więcej na temat koabitacji zob. W. Skrzydło, Konstytucja Rzeczypospolitej Polskiej. Komentarz, Warszawa 2013, s. 251-252.

49 Zob. np. Stanowisko w sprawie uchwalonych w Sejmie dnia 28 marca 2020 r. ustaw o szczególnych rozwiązaniach związanych z zapobieganiem, przeciwdziałaniem i zwalczaniem COVID-19, 
„izby refleksji”. Szczególnie w tym okresie naświetliła się szeroko zakrojona działalność legislacyjna Senatu, którego działania skupiły się stricte na korygowaniu błędów i wprowadzaniu nowych rozwiązań w obrębie uchwalonych uprzednio aktów sejmowych. Warto przy tym zauważyć, że do samych czterech ustaw dotyczących w swej istocie przeciwdziałania rozprzestrzenianiu się koronawirusa (to jest ustawa $\mathrm{z}$ dnia 31 marca 2020 roku o zmianie niektórych ustaw w zakresie systemu ochrony zdrowia związanych z zapobieganiem, przeciwdziałaniem i zwalczaniem COVID-19; ustawa z dnia 31 marca 2020 roku o zmianie ustawy o szczególnych rozwiązaniach związanych z zapobieganiem, przeciwdziałaniem i zwalczaniem COVID-19, innych chorób zakaźnych oraz wywołanych nimi sytuacji kryzysowych oraz niektórych innych ustaw; ustawa z dnia 16 kwietnia 2020 roku o szczególnych instrumentach wsparcia $\mathrm{w}$ związku $\mathrm{z}$ rozprzestrzenianiem się wirusa SARS-CoV-2; ustawa z dnia 14 maja 2020 roku o zmianie niektórych ustaw w zakresie działań osłonowych w związku z rozprzestrzenianiem się wirusa SARS-CoV-2) ${ }^{50}$ izba wyższa uchwaliła łącznie dokładnie 273 poprawki. Nie inaczej postąpiono w wypadku ustawy o szczególnych zasadach organizacji wyborów powszechnych na Prezydenta Rzeczpospolitej Polskiej zarządzonych w 2020 roku $^{51}$, kiedy to do aktu mającego łącznie 29 artykułów Senat zaproponował wprowadzenie 36 modyfikacji. Bez cienia wątpliwości za właściwą należy uznać działalność w ramach inicjatywy ustawodawczej, której efektem jest osiem projektów ustaw wniesionych do Sejmu.

Statystyki prowadzone przez Biuro Analiz, Dokumentacji i Korespondencji ${ }^{52}$ kreują jednoznaczny obraz wpisujący się w koncepcję „izby refleksji i rozwagi”, co stanowi przeciwieństwo aktywności gremium IX kadencji ${ }^{53}$. Konkretyzując bowiem to stwierdzenie, obecny Senat zgłosił poprawki do 43,6\% ustaw skierowanych przez Sejm, co oznacza blisko dwukrotny wzrost względem lat 2015-2019 i de facto tożsame jest ze średnią z ponad 30 lat. Przyjęto ponadto 21 na 65 aktów bez zgłoszenia jakichkolwiek modyfikacji. Obraz ten uzupełnia liczba 17 ustaw, względem których przyjęto wszystkie albo część proponowanych zmian (na 24) ${ }^{54}$. Uzasadnia to, że pomimo wrogiej politycznie większości w Sejmie posłowie potrafią docenić rzetelną pracę senatorów, opartą często na działaniu w zgodzie

Krakowski Instytut Prawa Karnego Fundacja, Kraków 2020, https://kipk.pl/dokumenty/stanowiskokoronawirus.pdf (dostęp: 18.06.2020).

50 Dz.U. poz. 567; Dz.U. poz. 568; Dz.U. poz. 695; Dz.U. poz. 875.

51 Dz.U. poz. 979.

52 Prace Biura dostępne są pod adresem: https://www.senat.gov.pl/prace/senat/opracowania-biura-analiz-dokumentacji-i-korespondencji (dostęp: 18.06.2020).

53 Liczbowe zestawienie ustaw rozpatrzonych przez Senat $w$ latach 1989-2020 na dzień 16 czerwca 2020 roku, Biuro Analiz, Dokumentacji i Korespondencji Kancelarii Senatu, https:// www.senat.gov.pl/gfx/senat/userfiles/_public/k8/statystyki/podstawowe_dane_10/07_ustawy_i_ poprawki_1-10.pdf (dostęp: 18.06.2020).

54 Ibidem, s. 2. 
z opiniami i ekspertyzami. Efektem racjonalnego i efektywnego współdziałania obu izb może być wyłącznie podniesienie jakości stanowionego w Rzeczypospolitej Polskiej powszechnie obowiązującego prawa, którego wartość zostanie dostrzeżona w tym szczególnym czasie zagrożenia epidemicznego.

Wynikająca z szerokiego rozumienia art. 2 współczesnej konstytucji zasada pewności i przewidywalności prawa należy bowiem do kanonu podstaw demokratycznego państwa prawnego ${ }^{55}$. Prima facie ustrojodawca, decydując się na utrzymanie dwuizbowego parlamentu asymetrycznego, wybrał model ,izby rozwagi i refleksji”. Twierdzenie takie jest możliwe do zbudowania na podstawie wykładni językowej samej ustawy zasadniczej, wskazując na przywoływany już art. 99 ust. 2 oraz przepisy rozdziału czwartego. Stosunkowo ograniczone kompetencje Senatu w ramach procedury ustawodawczej i możliwość łatwego odrzucenia veta przez większość sejmową nie oznacza bynajmniej braku realnego wpływu na legislację. Teza ta nabrała aktualności w kilku minionych miesiącach, łagodząc podawane w wątpliwość procedury stosowane przez Sejm oraz mizerną jakość norm zawartych w aktach prawnych. Doświadczenie, rozwaga i racjonalne spojrzenie senatorów korzystających z przysługujących ciału konstytucyjnych 30 dni „do namysłu” (art. 121 ust. 2) dokapitalizowało merytorycznie projekty aktów powszechnie obowiązujących i uzyskało wartość, którą zaprzepaszczono w toku prac izby IX kadencji. Z tego względu pozytywnie należy wypowiedzieć się o istnieniu Senatu jako drugiej izby rodzimego parlamentu, gdyż każde wyważone działanie w ramach ustawodawstwa powoduje ochronę obywateli przed państwem dysponującym władztwem i aparatem przymusu.

\section{Bibliografia}

\section{Literatura}

Antoszewski A., Władza ustawodawcza, [w:] Systemy polityczne współczesnej Europy, red. A. Antoszewski, R. Herbut, Warszawa 2007.

Binkowski H., Althing — najstarszy parlament w Europie, http://www.islandia.org.pl/althing.html. Constitution of the People's Republic of China, http://www.npc.gov.cn/zgrdw/englishnpc/Constitution/2007-11/15/content_1372965.html.

Czarny P., Problem zasadności istnienia dwuizbowego parlamentu w Polsce, [w:] Prawo konstytucyjne RP, red. P. Sarnecki, Warszawa.

Dargas M., W jakim kierunku zmierza prawo Chińskiej Republiki Ludowej - ku systemowi common law czy ku kompleksowej kodyfikacji prawa?, „Gdańskie Studia Azji Wschodniej” 1, 2012.

Dziadzio A., Koncepcja państwa prawa w XIX w. Idea a rzeczywistość, „Czasopismo Prawno-Historyczne" 62, 2005.

Dziadzio A., Powszechna historia prawa, Warszawa 2012.

55 M. Florczak-Wątor, Komentarz do artykułu 2, [w:] Konstytucja Rzeczypospolitej Polskiej. Komentarz..., s. 27-32.

(C) for this edition by CNS 
Florczak-Wątor M., Komentarz do artykułu 2, [w:] Konstytucja Rzeczypospolitej Polskiej. Komentarz, red. P. Tuleja, Warszawa 2019.

Helmholz R.H., Magna Carta and the ius commune, „University of Chicago Law Review” 66, 1999, nr 2.

Kallas M., Krzymkowski M., Historia ustroju i prawa w Polsce 1772/1795-1918. Wybór źródet, Warszawa 2006.

Karczewski: Senat będzie izba refleksji i zadumy, http://www.polsatnews.pl/wiadomosc/2016-01-03/ karczewski-senat-bedzie-izba-refleksji-i-zadumy.

Klepka R., Zasady funkcjonowania parlamentu dwuizbowego $w$ demokratycznym państwie unitarnym — przypadek Polski, https://www.academia.edu/16436104/Zasadność_funkcjonowania parlamentu_dwuizbowego_w_demokratycznym_państwie_unitarnym_przypadek_Polski.

Koszowski M., Medieval Iceland: The influence of culture and tradition on law, „Scandinavian Studies" 86, 2014, nr 3.

Kuwejt. Ustrój polityczny, [w:] Encyklopedia powszechna PWN, https://encyklopedia.pwn.pl/haslo/ Kuwejt-Ustroj-polityczny;4574593.html.

Markiewicz M., Rzeczpospolita bez sejmu. Funkcjonowanie państwa, [w:] Między barokiem a oświeceniem, Olsztyn 1996.

Marszatek Karczewski: Senat to izba refleksji i zadumy, http://telewizjarepublika.pl/marszalek-karczewski-senat-to-izba-refleksji-i-zadumy,43849.html.

Mattes R.B., South Africa: Democracy without the people?, „Journal of Democracy” 13, 2002, nr 1.

Opaliński E., Sejm srebrnego wieku, 1587-1652, Warszawa 2001.

Parliament of India. Lok Sabha. House of the People, https://loksabha.nic.in.

Polarczyk K., Parlament polski na tle parlamentów innych państw. Analiza statystyczna, „Biuro Studiów i Ekspertyz" 214, 2003.

Radziewicz P., Komentarz do artykułu 99, [w:] Konstytucja Rzeczypospolitej Polskiej. Komentarz, red. P. Tuleja, Warszawa 2019.

Rasch B.E., Electoral systems, parliamentary committees, and party discipline: The Norwegian storting in a comparative perspective, [w:] Party Discipline and Parliamentary Government, Columbus 1999.

Riksdagens historia, http://www.riksdagen.se/sv/sa-funkar-riksdagen/demokrati/riksdagens-historia.

„, Senat jest symbolem wolnej, suwerennej i niepodległej Polski”. Prezydent Duda otwiera posiedzenie izby wyższej parlamentu, https://wpolityce.pl/polityka/271569-senat-jest-symbolem-wolnej-suwerennej-i-niepodleglej-polski-prezydent-duda-otwiera-posiedzenie-izby-wyzszej-parlamentu-przemowienie.

Składowski K., Izba Żupanii jako element systemu konstytucyjnego w Republice Chorwacji, „Przegląd Prawa Konstytucyjnego" 2010, nr 2-3.

Skrzydło W., Konstytucja Rzeczypospolitej Polskiej. Komentarz, Warszawa 2013.

The Socialist Constitution of the Democratic People's Republic of Korea, http://www.naenara.com. $\mathrm{kp} / \mathrm{en} /$ politics.

Ting, [w:] Encyklopedia powszechna PWN, https://encyklopedia.pwn.pl/haslo/ting;3987418.html.

Uruszczak W., Historia państwa i prawa polskiego, t. 1. 966-1795, Warszawa 2010.

Wenezuela. Ustrój polityczny, [w:] Encyklopedia powszechna PWN, https://encyklopedia.pwn.pl/ haslo/Wenezuela-Ustroj-polityczny;4575675.html.

Wroński P., Po co PO 4 × TAK, http://wyborcza.pl/1,76842,2417025.html?disableRedirects=true.

Studenckie Prace Prawnicze, Administratywistyczne

i Ekonomiczne 33, 2020

(C) for this edition by CNS 


\section{Raporty}

Democracy Index 2017, https://www.eiu.com/topic/democracy-index.

Global parliamentary report. The changing nature of parliamentary representation, http://archive. ipu.org/pdf/publications/gpr2012-full-e.pdf.

Liczbowe zestawienie ustaw rozpatrzonych przez Senat w latach 1989-2020 na dzień 16 czerwca 2020 roku, Biuro Analiz, Dokumentacji Korespondencji Kancelarii Senatu, https://www.senat. gov.pl/gfx/senat/userfiles/_public/k8/statystyki/podstawowe_dane_10/07_ustawy_i_poprawki_1-10.pdf.

Opracowania Biura Analiz, Dokumentacji i Korespondencji, https://www.senat.gov.pl/prace/senat/ opracowania-biura-analiz-dokumentacji-i-korespondencji.

Podstawowe dane statystyczne o pracy Senatu IX kadencji, Biuro Analiz, Dokumentacji i Korespondencji Kancelarii Senatu, https://www.senat.gov.pl/gfx/senat/userfiles/_public/k8/statystyki/podstawowe dane 9/01_podstawowe_statystyki.pdf.

Population Distribution by Citizenship Status, https://www.kff.org/other/state-indicator/distribution-by-citizenship-status/?dataView $=1 \&$ currentTimeframe $=0$ \&sortModel $=\% 7 \mathrm{~B}$.

Sprawozdanie z wykonania budżetu państwa za okres od 1 stycznia do 31 grudnia 2017 r. (druk nr 2559), t. 1, http://orka.sejm.gov.pl/Druki8ka.nsf/0/42EEAAA67DED2F09C125829D002EC6C1 /\%24File/2559-Tom-I.pdf.

Stanowisko w sprawie uchwalonych w Sejmie dnia 28 marca 2020 r. ustaw o szczególnych rozwiazaniach zwiazanych z zapobieganiem, przeciwdziałaniem i zwalczaniem COVID-19, Krakowski Instytut Prawa Karnego Fundacja, Kraków 2020, https://kipk.pl/dokumenty/stanowiskokoronawirus.pdf.

The responsibilities of the Federal Council, https://www.parlament.gv.at/ENGL/PERK/NRBRBV/ BR/AUFGBR/index.shtml. 